\title{
Tropical Atlantic Water within the Benguela upwelling system at $27^{\circ} \mathrm{S}$
}

\author{
Arnold L. Gordon, ${ }^{*}$ Kathryn T. Bosley $\dagger$ and Frank Aikman III $\dagger$ \\ (Received 17 November 1993; in revised form 12 May 1994; accepted 13 May 1994)
}

\begin{abstract}
A CTD- $\mathrm{O}_{2}$ and $\mathrm{ADCP}$ section across the African Atlantic continental margin near $27^{\circ}$ S, obtained during R.R.S. Discovery cruise 165B in May 1987, reveals the water mass structure and associated velocity field of the shelf and upper slope of the Benguela upwelling system. Continental shelf water upwelling within the Benguela Current is drawn from the $12^{\circ} \mathrm{C}$ (about 200 $\mathrm{m}$ ) level. The upwelling water is drawn from oxygen depleted, tropical South Atlantic thermocline water that is advected along the shelf floor by a southward flowing subsurface current. Lower thermocline and intermediate water from the tropical South Atlantic are also observed flowing southward over the continental slope. Tropical Atlantic water generally resides north of the Angola-Bengucla Front at $16^{\circ} \mathrm{S}$. A narrow band of upwelled water is observed well seaward of the shelf, along the western edge of a large Agulhas eddy, indicating that Agulhas eddies play a role in stirring eastern boundary upwelled water into the ocean interior. These eddies also draw into the interior tropical Atlantic water found over the upper continental slope. The net transport between the 120 and 350 isobaths as measured by the ship-mounted ADCP, referenced to the sea floor, is $0.9 \times 10^{6} \mathrm{~m}^{3} \mathrm{~s}^{-1}$ to the south, with $1.6 \times 10^{6} \mathrm{~m}^{3} \mathrm{~s}^{-1}$ of southward flowing tropical Atlantic water and $0.7 \times 10^{6} \mathrm{~m}^{2} \mathrm{~s}^{-1}$ of northward flowing upwelled surface water. The tropical thermocline water mass advected to the south is not observed offshore within the northward flowing Benguela Current, in an unaltered state, thus the $0.9 \times 10^{6} \mathrm{~m}^{3} \mathrm{~s}^{-1}$ must feed shelf upwelling south of $27^{\circ} \mathrm{S}$, implying a net offshore flux of upwelled water between Lüderitz $\left(26^{\circ}\right)$ and Cape Columbine $\left(33^{\circ} \mathrm{S}\right)$.
\end{abstract}

\section{INTRODUCTION}

IN April/May 1987 R.R.S. Discovery cruise 165B obtained a series of CTD stations crossing the Benguela Current from $30^{\circ} \mathrm{S}, 2^{\circ} \mathrm{E}$ to the African continental shelf near $26^{\circ} 45^{\prime} \mathrm{S}$ (Fig. 1; Mele et al., 1990). The northward flowing Benguela Current may be considered as the eastern limb of the South Atlantic subtropical gyre. Often a name distinction is made between the inner coastal segment and the offshore deep ocean component. The offshore flow is now more frequently considered as the Benguela Current, though in older literature the term Southeast Trade Wind Drift is used, with the term Benguela Current reserved for the inshore component. The coastal component is also referred to as the Benguela upwelling system or Benguela Jet. Shannon (1985), Peterson and Stramma (1991) and ReID (1989) provide oceanographic overviews of the Benguela Current and surrounding ocean. We prefer to use just the term Benguela Current for the entire span of the northward flow.

GoRdon and HAXDY (1990) discuss the deep ocean component of the 1987 R.R.S.

${ }^{*}$ Lamont-Doherty Earth Observatory, Palisades, New York, NY 10964, IJ.S.A

$†$ NOAA/National Ocean Service, 1305 East-West Highway, Silver Spring, MD 20910, U.S.A. 


\section{longitude}

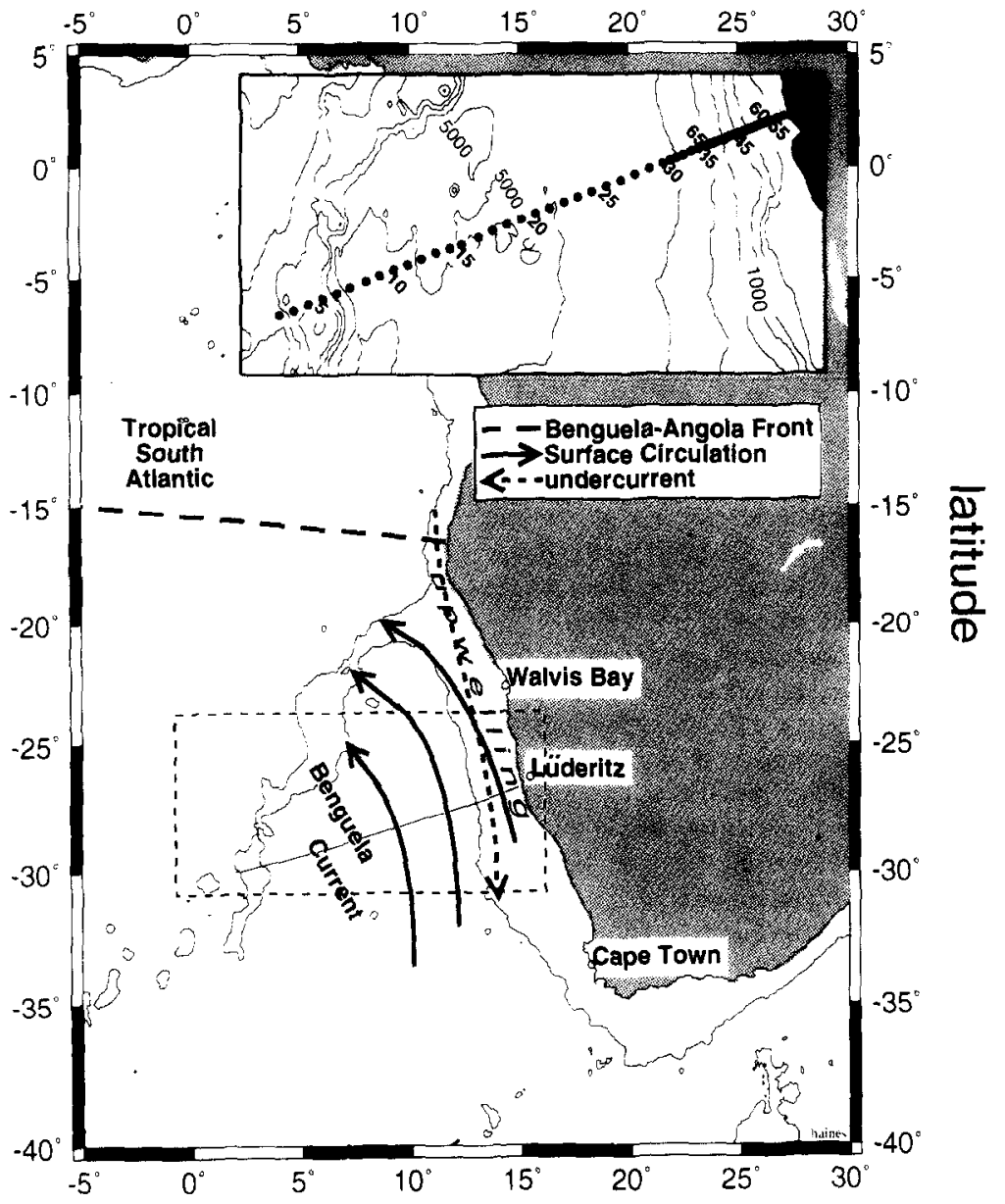

Fig. 1. Distribution of CTD stations obtained in April-May 1987 aboard cruise 165B of the R.R.S. Discovery (MELE et al., 1990). The area blocked out by the dashed line is detailed in the insert at the top of the figure. The north directed surface flow of the Bengucla Current is shown by solid arrows. The southward flowing undercurrent over the continental margin, discussed in the text, is shown by a dashed arrow. The thicker east-west oriented dashed line near $15^{\circ} \mathrm{S}$ is the Benguela-Angola Front, which separates the subtropical from the tropical South Atlantic oceanic regimes.

Discovery cruise 165B section, including a large Agulhas eddy centered between Stas 16 and 20 . In this study the water mass and velocity field of the Benguela Current over the continental margin, east of Sta. $27\left(11^{\circ} \mathrm{E}\right)$, is discussed. The eastern end of the section is located at the rather narrow continental shelf adjacent to Lüderitz, which is a center of coastal upwelling (Stander, 1964; Nelson and Hutchings, 1983; Shannon, 1985; Lutjeharms and Meeuwis, 1987). Upwelling is maximum in austral Spring, minimum in Fall (Shannon, 1985), the time of the R.R.S. Discovery 165B section. Discovery Stas 3557 , with a station spacing of less than $10 \mathrm{~km}$, offer a high resolution view of the stratification over the slope and shelf. Bottom tracked Acoustic Doppler Current Profiler 
(ADCP) data provide absolute velocity field data for regions of water depth less than $400 \mathrm{~m}$.

\section{THERMOHALINE AND OXYGEN STRATIFICATION}

The temperature and salinity sections (Fig. 2a, b) show shallowing isopleths as the coast is approached. An obvious exception is the reversal of the east-west slope for the water colder than $10^{\circ} \mathrm{C}$ and less saline than 34.9 near the sea floor. This results in a relatively thick layer of $10^{\circ}-12^{\circ} \mathrm{C}$ water with salinity of $34.9-35.0$ over the continental shelf, which is also grcatly depleted in oxygen concentration (Fig. 2c).

The average temperature and salinity of the upper $50 \mathrm{~m}$ (representing the Ekman Layer; Fig. 3) increase with distance from shore. The increases in both temperature and salinity are correlated from the coast to Sta. 35 (near $13^{\circ} \mathrm{E}$ ). From Sta. 35 westward to 32 further temperature change is diminished remaining close to $20^{\circ} \mathrm{C}$, though the salinity increases rather abruptly from 35.1 to 35.7 . It is suggested that the salinity front, falling between $12^{\circ}$ and $13^{\circ} \mathrm{E}$ near $27^{\circ} \mathrm{S}$ and over the $3500 \mathrm{~m}$ isobath, marks the western boundary of the eastern boundary upwelling regime. The regional surface temperature has attained close equilibrium with the local atmosphere, but the surface salinity, being less closely coupled with the local atmosphere, still bears a value close to its origin. East of the front the water is derived from the upwelled (from near the $12^{\circ} \mathrm{C}$ isotherm depth, as discussed below) water of the continental margin. West of the front the surface water is derived from the subtropical ocean, either from the Agulhas Retroflection (Indian Ocean subtropical water) or from the interior of the South Atlantic subtropical gyre. An Agulhas source, derived from the surface water entering the Atlantic from the Agulhas Bank and flowing immediately west of the upwelling centers as mentioned by SHANNON (1985) and by BANG and Andrews (1974), is favored. Gordon et al. (1992) show that the surface and thermocline water of the Benguela Current is primarily Agulhas in origin, particularly within its easternmost bounds. Additionally, saline South Atlantic subtropical water, flowing within the South Atlantic Current, may fold back into the South Atlantic subtropical gyre within the western edge of the Benguela Current, well west of $10^{\circ} \mathrm{E}$.

While the surface temperature shows weak response to the $12^{\circ}-13^{\circ} \mathrm{E}$ front, the subsurface isotherms (Fig. 2a) are strongly sloped at $12^{\circ}-13^{\circ} \mathrm{E}$ salinity front, suggesting that the front is marked by a northward flowing baroclinic jet. The surface geostrophic velocity relative to $1500 \mathrm{db}$ reaches $50-60 \mathrm{~cm} \mathrm{~s}^{-1}$. It is likely that the $12^{\circ}$ to $13^{\circ} \mathrm{E}$ feature is the northward extension of the Good Hope Jet and Cape Columbine Jet (approximately $100 \mathrm{~cm} \mathrm{~s}^{-1}$ found near the latitude of Cape Town as described by BANG and ANDREwS (1974), SHANNON (1985) and Boyd et al. (1992) which also marks the offshore extent of the upwelling water. Boyd et al. (1992) observe that the Columbine Jet bifurcates north of Cape Columbine, with the dominant branch turning seaward and a weaker branch following the shelf break. Recognizing that the jet is likely to be highly convoluted as filaments of upwelled water protrude into the interior and perhaps not always intact as a continuous feature (VAN Foreest et al., 1984; LUTJEHARMS and StOCKTON, 1987; LUTJEHarms et al., 1991; Shillington et al., 1990, 1992; Duncombe-RaE et al., 1992), it is proposed that the offshore branch of the Columbine Jet accounts for the $12^{\circ}-13^{\circ} \mathrm{E}$ front observed by the Discovery $165 \mathrm{~B}$ section.

The oxygen section (Fig. $2 \mathrm{c}$ ) shows that the shelf water of $10^{\circ}-12^{\circ} \mathrm{C}$ temperature is very depleted in oxygen, with values falling to less than $1 \mathrm{ml} \mathrm{l}^{-1}$. Water with oxygen 
(a)

Discovery 165b

Potential Temperature

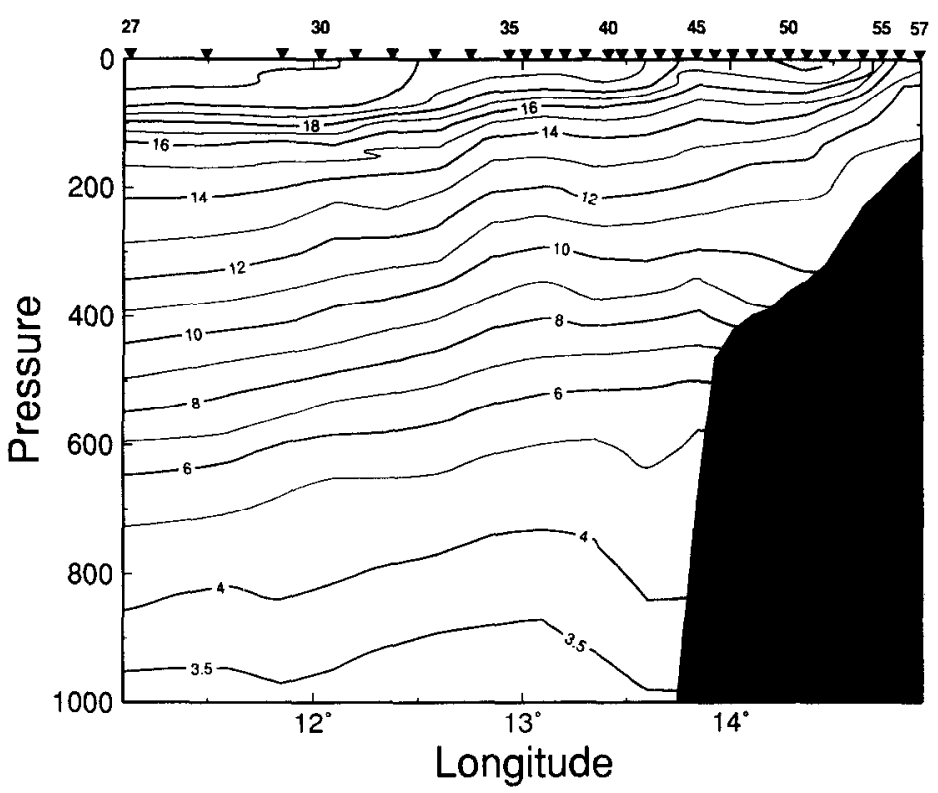

(b)

\section{Discovery $165 b$}

\section{Salinity}

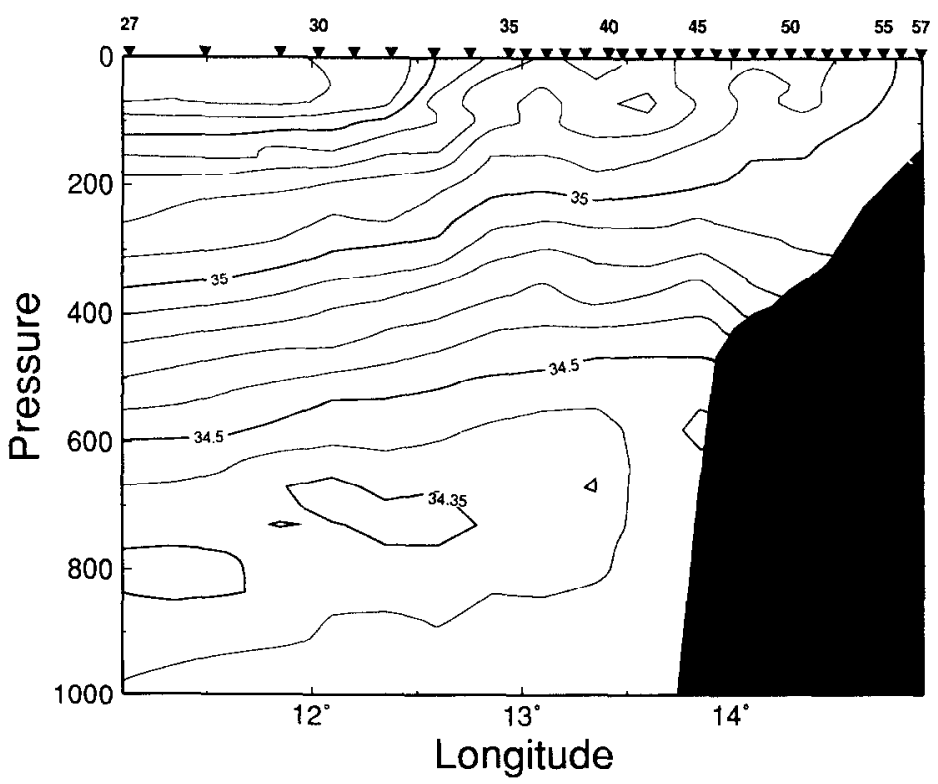

Fig. 2. (a) Potential temperature of the upper $1000 \mathrm{~m}$ for Discovery 165B stations east of 27.

(b) Salinity of the upper $1000 \mathrm{~m}$ for Discovery $165 \mathrm{~B}$ stations east of 27 . (c) Oxygen concentration of the upper $1000 \mathrm{~m}$ for Discovery $165 \mathrm{~B}$ stations cast of 27. 
(c)

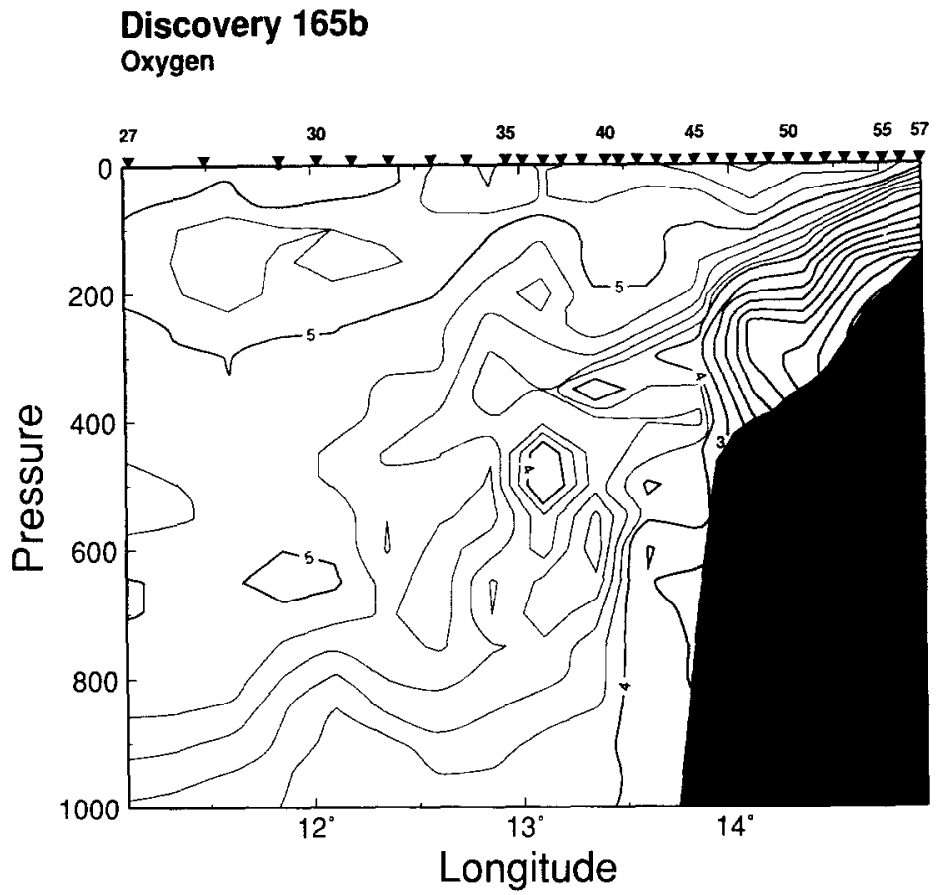

Fig. 2. Continued.

concentrations below $4 \mathrm{ml} \mathrm{l}^{-1}$ is found over the deeper continental slope. The oxygen depleted layers are marked by isotherm (which closely parallel the isopycnal) slope down towards the east, which indicates a southerly flow relative to a deep or bottom reference level, a direction supported by the ADCP (see section 3 below). Two isolated, relatively low oxygen cells in the $8^{\circ}-10^{\circ} \mathrm{C}$ interval are observed further offshore. These cells are embedded in a region of isotherm shallowing towards the east, where the geostrophic flow (relative to a deep reference level) is directed towards the north.

The potential temperature and salinity relationship (Fig. 4a) shows that for Stas $47-57$ in water less deep than $400 \mathrm{~m}$, the $T-S$ curve is nearly isohaline for water warmer than $12^{\circ} \mathrm{C}$. This isohaline layer is atmospherically warmed upwelled water, indicating that the upwelling is drawn from near the $12^{\circ} \mathrm{C}$ isotherm at a depth of $200 \mathrm{~m}$ or less. A near zero sum of precipitation plus runoff minus evaporation ensures little salinity change. For these stations, at water colder than $12^{\circ} \mathrm{C}$, the $T-S$ curve resides to the salty side of the main thermocline curve by about 0.05 in salinity (Fig. 4a). This water is markedly depleted in oxygen (Fig. 2c, 4b). As salinity is a conservative parameter, the high salinity indicates that the low oxygen is not solely a product of local consumption of oxygen, but rather an advective feature. A likely source of the shelf floor water is the relatively salty, low oxygen tropical thermocline water of the South Atlantic (GoRdon and Bosley, 1991). The Angola-Benguela Front separates the tropical thermocline from the Benguela Current thermocline. This front reaches the coastline near $16^{\circ} \mathrm{S}$ (MeEuwis and LuTIEHARMS, 1990), but clearly tropical Atlantic thermocline water extends much further to the south at subsurface levels over the continental shelf.

Poleward spreading of low oxygen tropical South Atlantic thermocline water by way of a 


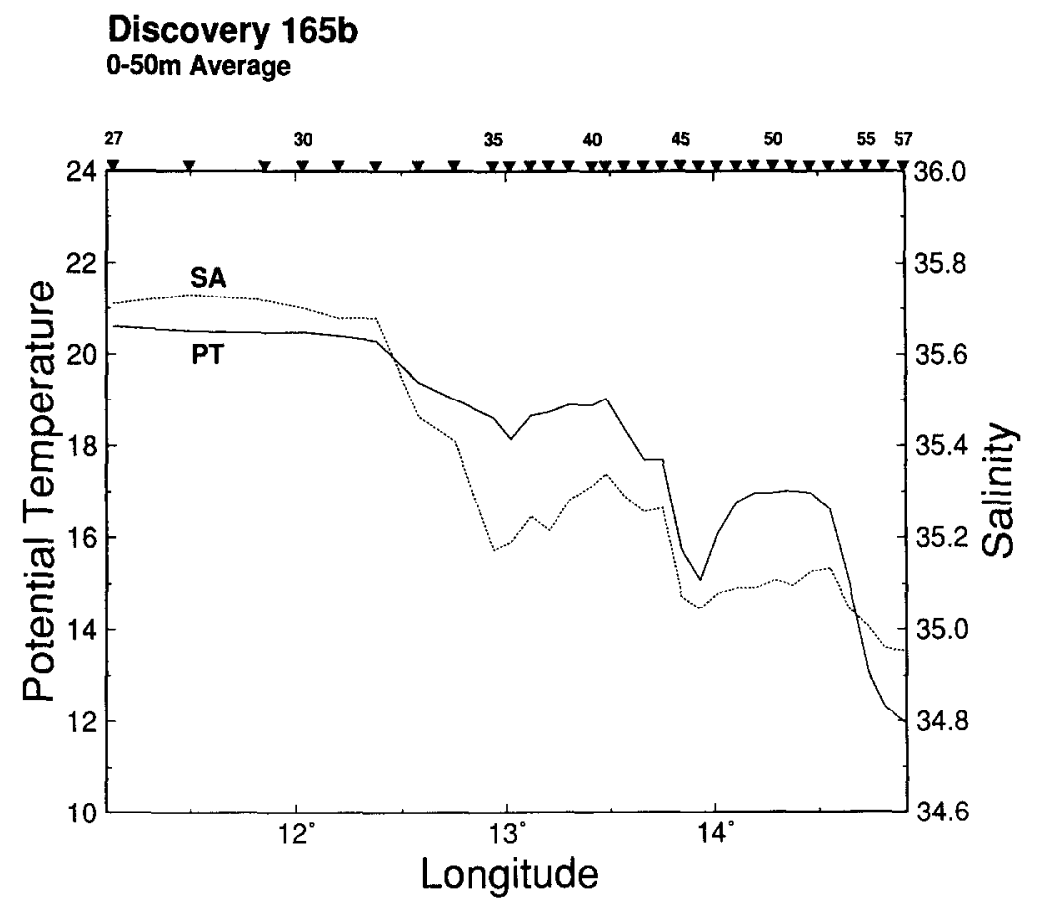

Fig. 3. Average potential temperature and salinity of the upper $50 \mathrm{~m}$ for Discovery $165 \mathrm{~B}$ stations east of 27.

subsurface current over the outer shelf has been reported before (HART and CURRIE, 1960; Stander, 1964; Shannon, 1985; Chapman and Shannon, 1985), although these authors indicate a southern limit of the poleward flowing undercurrent occurs near Lüderitz. Bailey (1979; also see Chapman and Shannon, 1985 and pages 144-149 of Shannon, 1985) finds low oxygen water over the outer shelf floor adjacent to Lüderitz in May 1976, a time when the dynamic topography study (geostrophic flow relative to $400 \mathrm{db}$ ) reveals poleward undercurrent. NELSON (1989) and Boyd et al. (1992) provide cvidence for at least an intermittent southward flowing undercurrent and inshore surface current as far south as Cape Columbine $\left(33^{\circ} \mathrm{S}\right)$, with a weak undercurrent to the latitude of Cape Town $\left(34^{\circ} \mathrm{S}\right)$.

The $T-S$ relationship for stations seaward of Sta. 27 (Stas 5-26 included in Fig. 4b; see GoRDON and HAXBY, 1990, for the temperature and salinity sections) for the most part does not show warmed upwelled water in the 35.1 salinity range as the stations are well west of the surface salinity front mentioned above (Fig. 3). However, a filament of low salinity (35.2) near surface water, which must be derived from the upwelled water is observed at Sta. 12 ( $6^{\circ} \mathrm{E}$; Fig. 4a). Station 12 falls along the western edge of the Agulhas eddy described by GORDON and HAXBY (1990). Clearly the eddy has entrained some upwelled water from the continental margin. Van Foreesi et al. (1984), Lutjeharms and Stockton (1987), Lutjeharms and Meeuwis (1987), Lutjeharms et al. (1991), Duncombe-RaE et al. (1992) and SHillington et al. $(1990,1992)$ show that filaments of upwelled surface water are entrained by offshore eddies, though some of the eddies they describe are not intense enough to be firmly labeled as Agulhas Eddies. The R.R.S. Discovery 165B section supports their conclusions. 


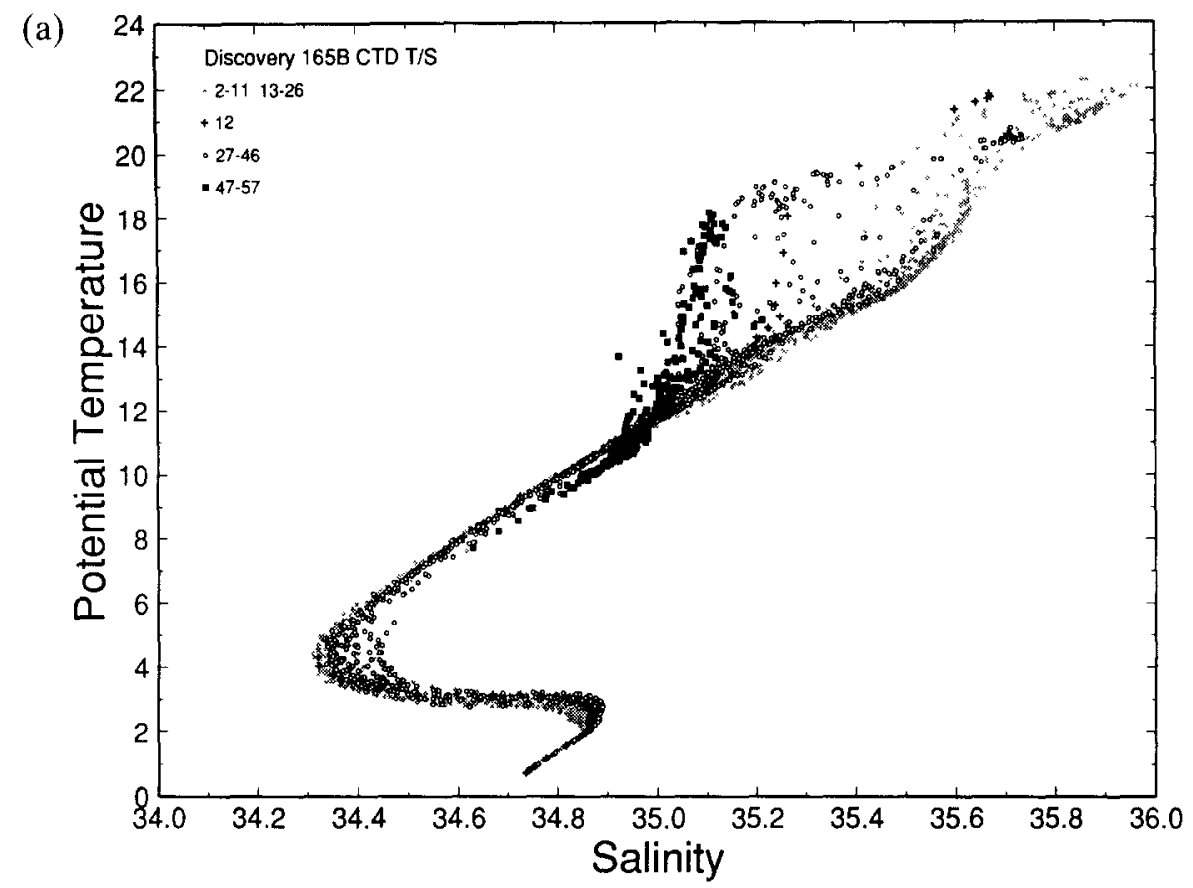

(b)

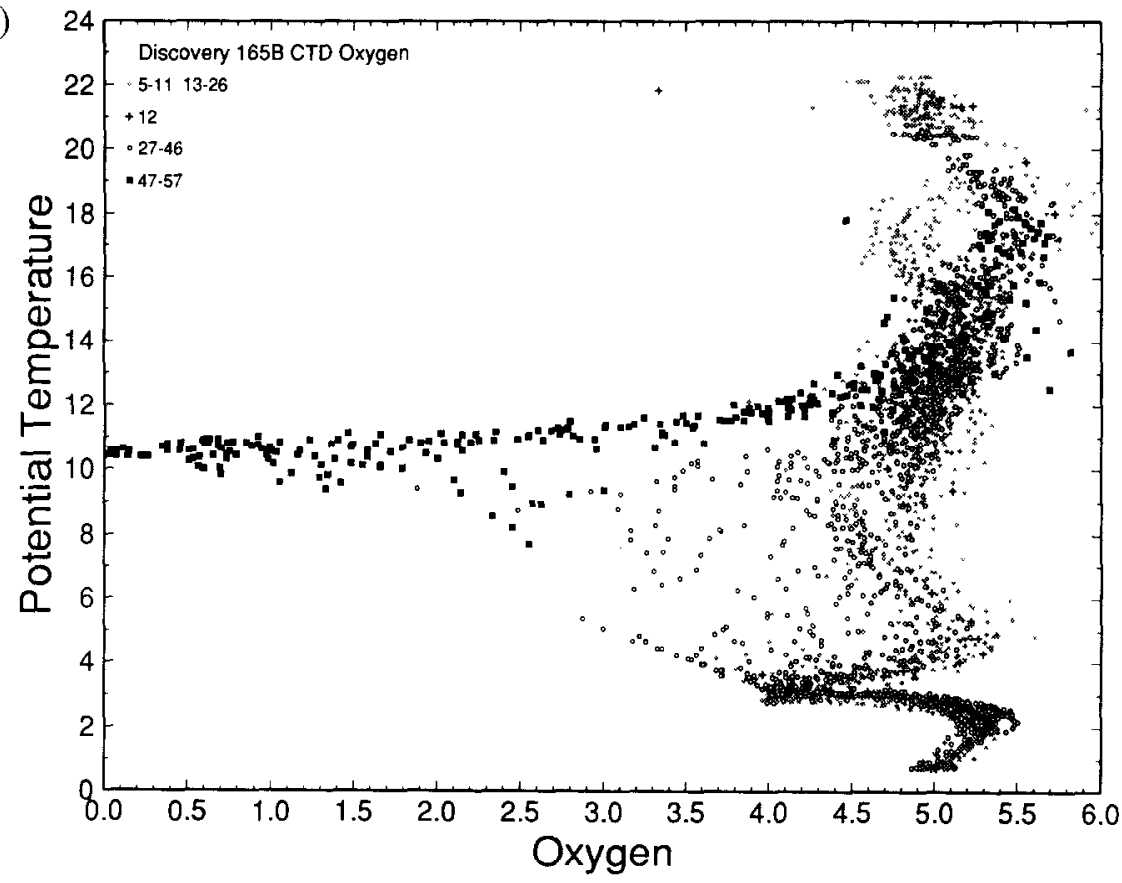

Fig. 4. (a) Potential temperature vs salinity for Discovery 165B CTD stations. The gray tone is for the stations west of Sta. 27, with Sta. 12 shown by "+". Stations $27-46$ are shown by an open circle. Stations $47-57$, for which bottom ADCP referenced data is available, are shown as solid boxes. (b) Potential temperature vs oxygen concentration for Discovery $165 \mathrm{~B}$ section. The symbols are the same as used in Fig. 4a. Data is derived from the rosette bottle samples obtained at each CTD station. 
The oxygen concentration is low over the continental slope, less than $4 \mathrm{ml} \mathrm{l}^{-1}$, with a $3.5 \mathrm{ml} \mathrm{l}^{-1}$ minimum near $600-700 \mathrm{~m}$, at a potential temperature of $4.5-5.5^{\circ} \mathrm{C}$ (Fig. $2 \mathrm{a}, \mathrm{c}$ ). This slope water falls within the density range of the Antarctic Intermediate water (AAIW), but is more saline by almost 0.1 in salinity (Fig. 4a). This water is also drawn from the tropical South Atlantic, since the AAIW is saltier with lower oxygen concentration than it is to the south of the Angola-Benguela Front (Gordon and BoSLEY, 1991). Therefore it appears that the poleward flow of tropical South Atlantic water extends from the shelf to the continental slope, as suggested by Stander (1964) and NeLSON (1989). GoRDON and BosLEY (1991) point out that North Atlantic Deep Water preferentially flows southward below the Benguela Current, indicating that southerly flow is characteristic of the full depth of the Atlantic continental margin of southern Africa.

McCartney and Woodgate-Jones (1991) discuss the presence of an Agulhas eddy along $23^{\circ} \mathrm{S}$ and $5^{\circ} \mathrm{W}$ crossed during a trans-Atlantic CTD section obtained from R.V. Oceanus in 1983 . They describe a low oxygen feature near $6^{\circ} \mathrm{C}$ and $600 \mathrm{~m}$ that they identify as a streamer of tropical Atlantic lower thermocline water, normally found one eddy diameter (about $300 \mathrm{~km}$ ) to the north. However, the route followed by the tropical Atlantic water to the " $23^{\circ} \mathrm{S}$ Oceanus" eddy may be longer than just one eddy diameter. Properties of the $6^{\circ} \mathrm{C}$ low oxygen feature within the " $23^{\circ} \mathrm{S}$ Oceanus" eddy agree quite well with the low oxygen slope water observed by R.R.S. Discovery $165 \mathrm{~B}$ near $27^{\circ} \mathrm{S}$, as well as the slope water observed at the eastern end of the $23^{\circ} \mathrm{S}$ Oceanus section (Oceanus Stas 125 , 126 and $127,12.76^{\circ}-12.98^{\circ} \mathrm{E}$ ). It is proposed that the oxygen depleted tropical Atlantic thermocline water observed within the " $23^{\circ} \mathrm{S}$ Oceanus" Agulhas Eddy is derived from the African continental slope well south of $23^{\circ} \mathrm{S}$. Gordon et al. (1992), describing an Agulhas eddy at $30^{\circ} \mathrm{S}$ and $6^{\circ} \mathrm{E}$, note the presence of a strong oxygen minimum just to its east. The elevated salinity within the $5^{\circ}-9^{\circ} \mathrm{C}$ interval of this oxygen depleted feature indicates that it is drawn from tropical relatively saline Atlantic lower thermocline water. This indicates that the slope water observed at $27^{\circ} \mathrm{S}$ on the Discovery cruise $165 \mathrm{~B}$ extends south of $30^{\circ} \mathrm{S}$.

The cruise $165 \mathrm{~B}$ data clearly reveals poleward advection of tropical South Atlantic lower thermocline water over the continental slope well to the south of the surface expression of the Angola-Benguela Front. The low oxygen filaments surrounding at least some of the Agulhas eddies indicate that the slope water is transferred seaward by interaction with the eddies, in a similar manner as the surface water described by LUTJEHARMS and MEEUwIS (1987), Duncombe-Rae et al. (1992), Lutjeharms and Meeuwis (1987), Shillington et al. (1992). Evacuation of slope water by those Agulhas eddies within "dynamic reach" of the African margin may be a common event.

Water mass analysis suggests a specific meridional circulation pattern over the continental margin and interaction with Agulhas eddies. In the case of shelf water this pattern may be studied more directly with the bottom referenced ADCP obtained on cruise $165 \mathrm{~B}$.

\section{VELOCITY}

Current velocity measurements were obtained using an RD Instruments Acoustic Doppler Current Profiler (ADCP) aboard the R.R.S. Discovery. These data permit transport values to be associated with the water mass structure, discussed above. The bin thickness used for this analysis is $8 \mathrm{~m}$.

Several pings are averaged into an ensemble at the end of a user determined sample interval. A sample interval of 5-min was used during this investigation. If the strength of a 


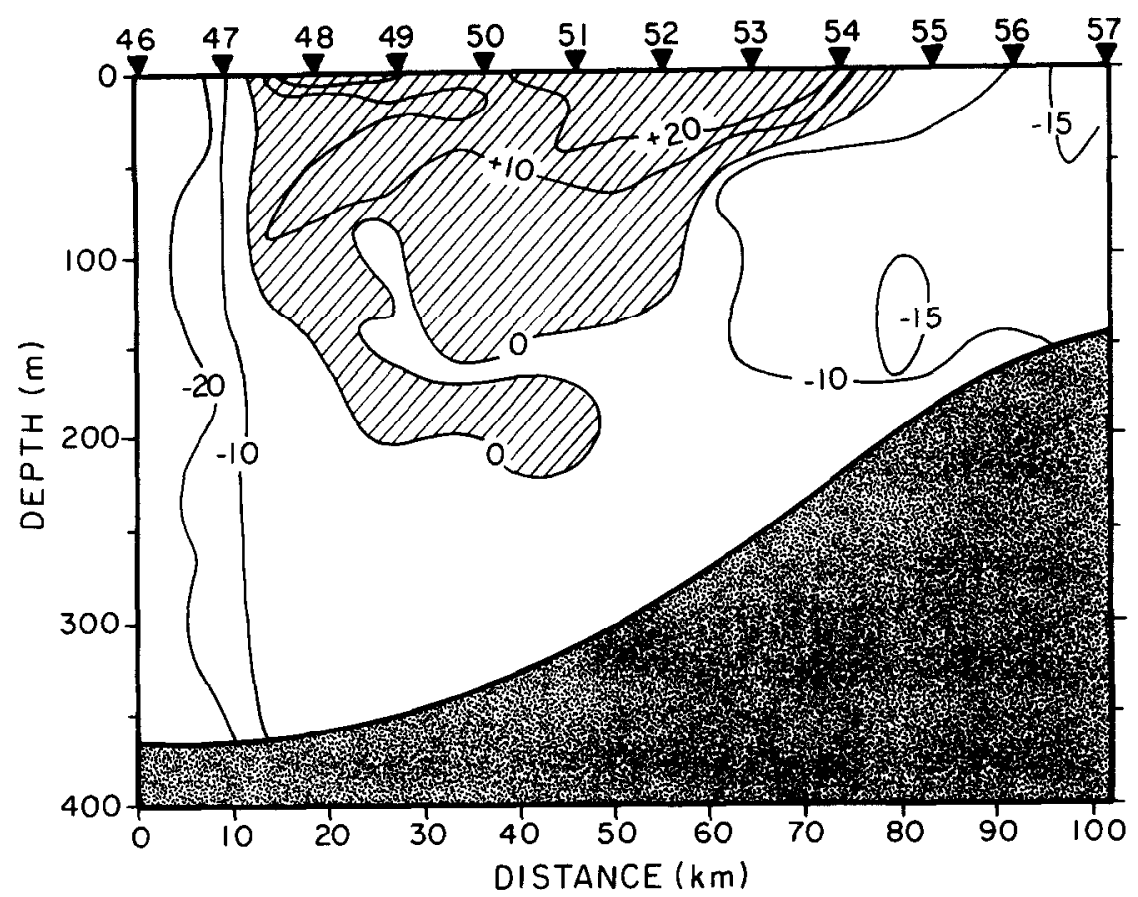

Fig. 5. ADCP derived velocities $\left(\mathrm{cm} \mathrm{s}^{-1}\right)$ perpendicular to the Discovery section east of Sta. 46 (see Fig. 1). Positive values denote flow to the north, negative values denote flow to the south.

return ping is below a predetermined noise level, the ping is not recorded. The percentage of good pings in an ensemble is a measure of the quality of the data.

The ADCP measurements of water velocity are relative to the ship, thus an independent measure of the ship's speed is necessary to determine the absolute velocity. The R.R.S. Discovery ADCP acquisition system during cruise 165B in 1987 did not record navigation, therefore accurate ship velocities through the water are only available when the ADCP system is in bottom tracking mode. In this mode, which is possiblc only when the bottom depth is $300-400 \mathrm{~m}$, the system picks up a bottom echo and calculates the ship's velocity without the use of navigation. Between CTD Stas 46 and 61 the bottom depth was sufficiently shallow as to allow calculation of absolute current velocities.

A section of current velocity from Sta. $46\left(26.96^{\circ} \mathrm{S}, 13.93^{\circ} \mathrm{E}\right)$ to the coast was obtained by first combining all the bottom tracking mode ensembles between each of the 16 station pairs $(46-47,47-48$, etc.) with more than $10 \%$ good data. The time when the ship was not accelerating between stations was then selected using the ship's log. Only data taken during these times of constant ship speed were used in the velocity calculations. The heading in the ADCP file was corrected because of the relationship mentioned above. The ship's bottom tracked velocity recorded with each ping file was subtracted from the ADCP water velocity. The mean and standard deviation of the resulting velocity were calculated for each depth interval (bin). The velocities shown in Fig. 5 represent component perpendicular to the CTD section, roughly along-shelf.

The ADCP recorded velocities show generally southeastward flow at all depths from Sta. 54 to the coast, and between Stas 46 and 47. Below $100 \mathrm{~m}$ the flow is also 
Table 1. Transport of the coastal segment of the Benguela Current $\left(\right.$ values in $\mathrm{Sv}=$ Sverdrups $\left.=1 \times 10^{6} \mathrm{~m}^{3} \mathrm{~s}^{-1}\right)$

\begin{tabular}{lcc}
\hline Station pair & SE transport (SV) & NW transport (Sv) \\
\hline $46-47$ & 0.552 & 0.000 \\
$47-48$ & 0.073 & 0.079 \\
$48-49$ & 0.081 & 0.141 \\
$49-50$ & 0.039 & 0.073 \\
$50-51$ & 0.006 & 0.122 \\
$51-52$ & 0.016 & 0.142 \\
$52-53$ & 0.126 & 0.090 \\
$53-54$ & 0.203 & 0.052 \\
$54-55$ & 0.182 & 0.000 \\
$55-56$ & 0.161 & 0.000 \\
$56-57$ & 0.169 & 0.000 \\
Total for the section & $1.61 \mathrm{~Sv}$ & $0.70 \mathrm{~Sv}$ \\
Net $=0.91$ Sv to the southeast & \\
\hline
\end{tabular}

southeastward between Stas 47 and 54 (Fig. 5). Strong northwestward surface flow (velocities greater than $20 \mathrm{~cm} \mathrm{~s}^{-1}$ ) is concentrated between Stas 47 and 54. BAILEY (1979; see pages 144-149 of SHANNon, 1985), using water masses and dynamic topography analysis of May 1976 data deduced the presence of a poleward current between 200 and 400 m depth, about 100-150 km offshore. The Discovery 165B direct ADCP data of May 1987 support Bailey's result. The transports accomplished by these velocities are given in Table 1.

The net transport is towards the south at a rate of $0.9 \mathrm{~Sv}\left(\mathrm{~Sv}=10^{6} \mathrm{~m}^{3} \mathrm{~s}^{-1}\right)$. About a third of the southward transport occurs between Stas 46 and 47 in slightly over $300 \mathrm{~m}$ water depth. The northward flow is confined to the upper $100 \mathrm{~m}$ between Stas 47 and 54 ranging in water depth of 200-300 m. Along these isobaths a northward jet has been observed further to the south extending from Cape Point $\left(34^{\circ} \mathrm{S}\right)$ to Cape Columbine $\left(33^{\circ} \mathrm{S}\right)$ often called the Cape Columbine Jet (Nelson and Hutchings, 1983). However, as the water within the southern jet is composed of warm, saline Agulhas Bank water, it is not the source for the northward flow measured by the R.R.S. Discovery ADCP over the outer shelf. The continuation of the Cape Columbine jet is more likely the water just west of the salinity front between $12^{\circ}$ and $13^{\circ} \mathrm{E}, 90 \mathrm{~km}$ west of the $400 \mathrm{~m}$ isobath, as discussed above.

\section{CONCLUSIONS}

Water mass analysis indicates that southward transport of tropical Atlantic thermocline water over the continental shelf floor at $27^{\circ} \mathrm{S}$ feeds the wind induced upwelling over the continental shelf adjacent to Lüderitz, near $27^{\circ} \mathrm{S}$. A net excess of southward transport across $27^{\circ} \mathrm{S}$ on the continental shelf of $0.9 \mathrm{~Sv}$ implies that this condition extends further south (1.6 Sv of southward flowing shelf floor water). Eventually the net southward flow must diminish to zero, presumably before reaching Cape Columbine at $33^{\circ} \mathrm{S}$, as it is drawn into the upwelling.

Assuming steady state a number of simple calculations can be performed. If all of the 1.6 $\mathrm{Sv}$ of southward flowing shelf floor water upwells over the continental shelf between $27^{\circ} \mathrm{S}$ 
and Cape Columbine the mean upwelling across the $12^{\circ} \mathrm{C}$ isotherm is $1.2 \times 10^{-5} \mathrm{~m} \mathrm{~s}^{-1}$. The assumption of nearly complete upwelling is valid, as the very low oxygen of the shelf floor water is not observed in significant volume west of the shelf break (filaments associated with eddies are observed). As only $0.7 \mathrm{~Sv}$ of upwelled water passes to the north across the shelf at $27^{\circ} \mathrm{S}$, some of the upwelled water must migrate westward over the shelf break, perhaps as filaments drawn out by offshore eddies. The offshore transport within the upwelled water, warmer than $12^{\circ} \mathrm{S}$, generally above $150-200 \mathrm{~m}$ depth, amounts to 0.9 Sv (the net transport over the shelf at $27^{\circ} \mathrm{S}$ ). The corresponding mean offshore velocity from Lüderitz to Cape Columbine is $6.8 \times 10^{-3} \mathrm{~m} \mathrm{~s}^{-1}$. This must account for the seaward spreading of upwelled water. An average meridional wind speed of $6 \mathrm{~m} \mathrm{~s}^{-1}$ is required to induce an Ekman offshore transport from $27^{\circ} \mathrm{S}$ to $33^{\circ} \mathrm{S}$ of $0.9 \mathrm{~Sv}$.

Duncombe-RAE et al. (1992) estimate that the volume of a shelf water filament encircling an Agulhas eddy is $5 \times 10^{12} \mathrm{~m}^{3}$. This amounts to an annualized flux of $0.16 \mathrm{~Sv}$ per Agulhas eddy, requiring 5-6 eddies per year to evacuate the $0.91 \mathrm{~Sv}$ accumulated upwelled water. LUTJEHARMS and VAN BALLEGOOYEN (1988) estimate an average eddy production of one every 39 days, or about $9 \mathrm{y}^{-1}$. About $60 \%$ of these, interacting with the upwelling system are required to account for the offshore flux of shelf water.

Water mass analysis indicates that the slope water at $27^{\circ} \mathrm{S}$ is derived from the lower thermocline and AAIW of the tropical South Atlantic. This water is entrained by passing Agulhas eddies. Perhaps there is a mean separation point for this water to leave the slope and flow along the inshore edge of the Benguela Current derived from the South Atlantic Current and Agulhas Current. However, sections which do not cross Agulhas eddies do not show the low oxygen water, so the eddies may be the primary removal mechanism.

Acknowledgements - The authors wish to thank the very competent staff of the R.R.S. Discovery for supporting the collection of the cruise 165B data. Comments of Christopher M. Duncombe-Rae were very helpful. The collection of the Discovery cruise 165B data was supported by ONR grant N0001 4-87-K0204, Scope SAI. The preparation of this manuscript was supported by NSF grant OCE 91-02722. Lamont-Doherty Earth Observatory Contribution number 5200 .

\section{REFERENCES}

Bailey G. (1979) Physical and chemical aspects of the Benguela Current in the Lüderitz Region. M.Sc. thesis, University of Cape Town, South Africa, $225 \mathrm{pp}$.

BANG N. and W. Andrews (1974) Direct current measurements of a shelf-edge frontal jet in the southern Benguela system. Journal of Marine Research, 32, 405-417.

Boyd A., J. TAunton-Clark and G. Oberholster (1992) Spatial features of the near-surface and mid-water circulation patterns off western and southern South Africa and their role in the life histories of various commercially fished species. In: Benguela trophic functioning, Payne, Brink, Mann and HiLbokn, editors, South African Journal of Marine Science, 12, 189-206.

Chapman P. and L. Shannon (1985) The Benguela ecosystem part II. Chemistry and related processes. Oceanography Marine Biology Annual Review, 23, 183-251.

Duncombe-Rae C., F. Shillington, J. Agenbag, J. Taunton and M. Grüdlingh (1992) An Agulhas ring in the South Atlantic and its interaction with the Benguela upwelling frontal system. Deep-Sea Research, 39. 2009-2027.

Gordon A. and W. HAxby (1990) Agulhas eddies invade the South Atlantic: evidence from Geosat altimeter and shipboard conductivity-temperature-depth survey. Journal of Geophysical Research, 95, 3117-3125.

Gordon A. and K. Busley (1991) Cyclonic gyre in the tropical South Atlantic. Deep-Sea Research, 38 (Suppl. 1), S323-S343

Gordon A., R. Weiss, W. SMEthie and M. WARner (1992) Thermocline and intermediate water communication between the South Atlantic and Indian Ocean. Journal of Geophysical Research, 97, 7223-7240. 
Hart T. and R. Currie (1960) The Benguela Current. Discovery Reports, 31, 123-298.

LutJeharms J. and J. Meeuwis (1987) The extent and variability of Southeast Atlantic upwelling. South African Journal Marine Science, 5, 51-62.

Lutjeharms J. and P. Stockton (1987) Kinematics of the upwelling front off southern Africa. South African Journal of Marine Science, 5, 35-49.

Lutjeharms J. and R. VAN Ballegooyen (1988) The retroflection of the Agulhas Current. Journal of Physical Oceanography, 18, 1570-1583.

Lutjeharms J., F. Shillington and C. M. Duncombe-Rae (1991) Observations of extreme upwelling filaments in the Southeast Atlantic Ocean. Science, 253, 774776.

MCCARTNEy M. and J. Woodgate-Jones (1991) A deep-reaching anticyclonic eddy in the subtropical gyre of the eastern South Atlantic. Deep-Sea Research, 38 (Suppl. 1), S411-S443.

Meeuwis J. and J. Lutjeharms (1990) Surface thermal characteristics of the Angola-Bengucla Front. South African Journal of Science, 9, 261-279.

Mele P., W. Haines, B. Huber and A. Gordon (1990) CTD and Hydrographic Data from Cruise $165 B$ of R.R.S. Discovery. LDGO Palisades, NY 10964 U.S.A. Technical report-90-2.

Nelson G. (1989) Poleward motion in the Benguela Current. In: Poleward flows along eastern ocean boundaries, Neshyba, Mooers, Smith and Barber, editors, Coastal and Estuarine Studies, Vol. 34, pp. 110-130.

Nelsun G. and L. Hutchings (1983) The Benguela Upwelling Area. Progress in Oceanography, 12, 333-356.

Peterson R. and L. Stramma (1991) Upper-level circulation in the South Atlantic. Progress in Oceanography, 26, $1-73$

ReID J. (1989) On the total geostrophic circulation of the South Atlantic Ocean: flow patterns, tracers and transport. Progress in Oceanography, 23, 149-244.

Shannon L. (1985) The Benguela Ecosystem Part I. Evolution of the Benguela, Physical Features and Processes. Oceanography Marine Biology Annual Review, 23, 105-182.

Shillington F., W. Peterson, L. Hutchings, T. Probyn, N. Waldron and J. Agenbag (1990) A cool upwelling filament off Namibia, southwest Africa: preliminary measurements of physical and biological properties. Deep-Sea Research, 37, 1753-1772.

Shillington F., L. T. Hutchings, H. W. Probyn and W. Peterson, (1992) Filaments and the Benguela Frontal Zone: offshore advection or recirculation loop? South African Journal Marine Science, 12, 207-218.

STANDER G. H. (1964) The pilchard of South West Africa (Sardinops ocellata), The Benguela Current off South West Africa. Adm of Southwest Africa, Marine Research Laboratory Investigational Report No. 12, 43 pp.

Van Foreest D., F. Shlllington and R. Legeckis (1984) Large scale, stationary, frontal features in the Benguela Current system. Continental Shelf Research, 3, 465-474. 